
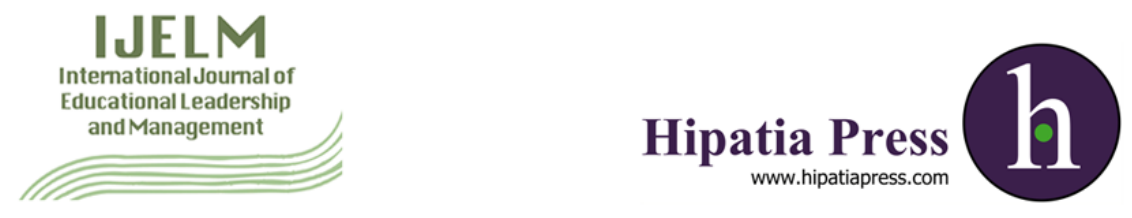

Instructions for authors, subscriptions and further details:

http://ijelm.hipatiapress.com

\title{
Leadership in Social Movements: The Case of Ojo con tu Ojo
}

Rosa Valls ${ }^{1}$, Adriana Aubert ${ }^{1}$, Lidia Puigvert ${ }^{1}$, Ainhoa Flecha ${ }^{2}$

1) University of Barcelona

2) Autonomous University of Barcelona

Date of publication: July $16^{\text {th }}, 2017$

Edition period: July 2017-December 2017

To cite this article: Valls, R., Aubert, A., Puigvert, L. \& Flecha, A. (2017) Leadership in Social Movements: The Case of Ojo con tu Ojo. IJELM, 5(2), 148-177. doi: 10.17853/ijelm.2017.2751

To link this article: http://dx.doi.org/10.17583/ijelm.2017.2751

\section{PLEASE SCROLL DOWN FOR ARTICLE}

The terms and conditions of use are related to the Open Journal System and to Creative Commons Attribution License (CC-BY). 


\section{Leadership in Social Movements: The Case of Ojo con tu Ojo}

Rosa Valls

University of Barcelona

Lídia Puigvert

University of Barcelona
Adriana Aubert

University of Barcelona

Ainhoa Flecha

Autonomous University of

Barcelona

\section{Abstract}

Leadership has been a topic of much interest in the analysis of social movements. Drawing from qualitative fieldwork, this article analyses the leadership that was developed by Ester Quintana, who was the last victim to be injured by a rubber bullet during a demonstration in Barcelona (Spain). Together with her friends and other people, Quintana created the Ojo con tu ojo movement (Watch out for your eye). Specifically, the article explores the relevance of Quintana's prior experiences in participatory and dialogic movements and identifies the way that she transferred this knowledge to Ojo con tu ojo as the key to the success of the movement. In only 12 months, Ojo con tu ojo achieved something that other similar social movements in Spain had not achieved in the past: a legislation change that bans the use of rubber bullets by the police.

Keywords: Rubber bullets, social movement, dialogic, leadership 


\section{El Liderazgo en Movimientos Sociales: \\ El Caso de Ojo con tu Ojo}

Rosa Valls

University of Barcelona

Lídia Puigvert

University of Barcelona

\author{
Adriana Aubert \\ University of Barcelona \\ Ainhoa Flecha \\ Autonomous University of \\ Barcelona
}

\section{Resumen}

El liderazgo ha sido un tema de gran interés en el análisis de los movimientos sociales. Partiendo de un trabajo de campo cualitativo este artículo analiza el liderazgo desarrollado por Ester Quintana, que fue la última víctima en ser herida por una bala de goma durante una manifestación en Barcelona (España). Junto con sus amigos y otras personas, Quintana creó el movimiento Ojo con tu ojo. En particular, el artículo profundiza en la relevancia de las experiencias anteriores de Quintana en movimientos participativos y dialógicos e identifica la forma en que transfirió este conocimiento a Ojo con tu ojo, aspecto que se considera clave para el éxito del movimiento. En sólo 12 meses, Ojo con tu ojo logró algo que otros movimientos sociales similares en España no habían logrado en el pasado: un cambio de legislación que prohibía el uso de balas de goma por parte de la policía.

Palabras clave: balas de goma, movimiento social, dialógico, liderazgo 

n November 14, 2012, the call for a general strike led to a peaceful and legal demonstration in Barcelona. During the final moments of this demonstration, Ester Quintana, a 42-year-old woman, was attacked by the police. The first moments after the incident were marked by uncertainty, but the information and the evidence that were uncovered showed that she was a victim of a legal projectile in Catalonia, namely, a rubber bullet, which was fired by a policeman. Ester had to be operated on that night. Three days later, the doctors confirmed that she had lost her left eye. The next day after the incident, a series of initiatives emerged among her friends, which lead to the creation of Ojo con tu ojo ${ }^{1}$, a solidarity platform. Because of the efforts of the Ojo con tu Ojo movement, Ester's story aroused public interest, and an official claim to determine what occurred became the central focus. Because of the activities that were undertaken by the movement, in less than a year, Ojo con tu ojo forced a legislative change that led lead to the ban of the use of rubber bullets by the security forces of Catalonia (Spain).

This study analyzes the case of Ojo con tu ojo and explores how the leadership that was exercised by Ester contributed to the success of the movement. In recent decades, the study of leadership has become a topic of interest in the literature on social movements and organizations, and it has become important to understand the influence of leadership on the outcomes of social movements and explore how it contributes to social change (Aminzade et al., 2001; Ganz, 2011; Melucci, 1996; Morris, 2000; Morris \& Staggernborn, 2004). Mainly, these scholars support the idea that the traditional $20^{\text {th }}$ century social theory on social movements has not typically examined the role of leadership as a key element to the social movements' effectivity and success. From this theoretical standpoint, a deep interest emerges in studying how effective forms of leadership have been informed by leaders' previous experiences in dialogic movements or in ascertaining the key role that social agency plays in shaping leadership in social movements and collective actions. The argument that is presented in this article is framed in the dialogic perspective that recognizes the potential of human agency to promote changes in social structures.

Drawing on prior work, the two research questions of this study are the following: 1) which previous experiences in the life of Ester strengthened her leadership skills? and 2) how has Ester transferred these previous experiences to Ojo con tu ojo? 
First, this article presents a literature review on effective leadership, social movements and the dialogical approach and emphasizes the need to identify real examples of the leadership on social movements that contribute to transform social structures. The methodology, data collection and analysis strategies that are used in this research are detailed next. Then, the results of our analysis are presented regarding the relevance of Ester's previous life experiences in social movements and dialogic organizations and the transference of these principles to the Ojo con tu ojo organization, which became an authentic social movement that banned the use of rubber bullets by the security forces in Catalonia.

\section{Leadership in Social Movements}

The works of scholars such as Einwohner (2007), Ganz (2010), Morris (2000), and Morris \& Staggenborg (2004) have been very relevant to explain how leadership determines the outcomes of social movements. In this regard, Morris and Staggenborg argued that movement leaders are strategic decision-makers who inspire and organize others to become involved. Because the motivations to participate in collective actions and social movements are not always the same (Gomez-Roman \& Sabucedo, 2014), these scholars suggest that social movement theory would benefit from an analysis of the different ways in which leaders can trigger social change and generate conditions that activate other potential participants' agency. Through sharing stories, socially constructing meanings and exploring new ideas, leaders develop the capacity to persuade other individuals to join their campaigns and movements (Morris \& Staggenborg, 2004). In addition, the ability of leaders to tell moving stories has been emphasized. The connection between leadership and narratives has been deeply explored by several authors (Couto, 1993; Davis, 2002; Ganz, 2011; Soler, 2015). Couto (1993) emphasized that these narratives provide the group with historical precedents of individual and collective resistance. Thus, narratives constitute a formative element of local leadership and emerge as a visible political element of social movements. Morris and Staggenborg's (2004) approach focuses on using narratives and encouraging their creation in shared spaces, and leaders offer frames, tactics and organizational vehicles that empower participants to construct a collective identity and engage in collective action. 


\section{Valls et al. - Leadership in Social Movements}

More recently, storytelling and social relations have been identified as key tools of leadership in social movements. Ganz (2000) defines leadership as accepting responsibility to create interpersonal, structural and procedural conditions to enable others to achieve a shared purpose in the face of uncertainty. Contrary to considering leadership as a position that is held by a single, charismatic individual in the traditional Weberian sense (Weber, 1978), Ganz conceives leadership as a process, a relationship that is created between leaders and their constituencies: leaders are the individuals who provide resources to their constituencies to address their interests and vice versa. As Ganz, a Harvard-based sociologist says, leadership requires engaging the "heart" (the values), the "head" (a strategy) and the "hands" (actions) of people, and it requires mobilizing their feelings and values (Ganz, 2010). When leaders organize, they tell a new story or adapt a public story that is based on their past personal experiences; this story is the collective story of "the us" and the story of the present situation that requires change now, which Ganz calls a public narrative. According to Ganz, this is a leadership art and the discursive process through which individuals, communities and nations make choices, construct identities, and inspire action. Thus, leaders use narratives to motivate people to act (Ganz, 2009). Ganz conceives leadership not only as the capacity to create a public narrative but also as a collective relationship, or leadership as a team. According to him, leaders can be at different levels and all of them can contribute to the formulation of a strategy, which is a core category in the process of organizing (Ganz, 2000). Ganz also addresses the importance of leaders' background and the likelihood that they will develop an effective strategy. According to him, the differences in strategic capacity can be attributed to the specificities of each leader's life experiences, the networks and repertories of collective actions and the deliberative process, and the resources and accountability structures of their organizations (Downey, 2006).

Ganz's idea of leaders' life experiences, networks and repertories of collective actions resembles what other scholars such as Morris and Staggernborn (2004) call the social composition of leadership when exploring how leaders with different backgrounds and experiences make different strategic choices. These choices, in turn, may cause social movements to either succeed or fail. Leaders shape and acquire their skills through very different means, namely, as an accumulation of previous life 
experiences; thus, leaders acquire their skills and are influenced by their social origins, life experiences, relationships and practical learning, which provide them with the lenses through which they see the world (Banaszak, 1996; Bandura, 1989; DiMaggio, 1997; DiMaggio \& Powell, 1991; Veltmeyer \& Petras, 2002; Zerubave, 1997) through the formal education and knowledge that is gained in their communities and prior movement experience. Morris \& Staggernborn (2004) indicate that pre-existing organizations and institutions have a major role in producing movement leaders.

Additionally, consistent with the importance of relationships in social movements, studies such as the one by Shemtov (2003) suggest that the establishment of friendships among social movements' participants promotes promote goal expansion.

There is consensus that leadership as conceived under the relationship approach is a constructed reality, which is influenced by individuals' life experiences and their background. In this regard, the literature analyzes how the participation in civic associations or other similar public spaces of dialogue constitutes a source of inspiration for its members in terms of promoting collective actions and shaping leadership skills (Lynch, 2016).

In this regard, Padrós \& Flecha (2014) have coined the concept of dialogic leadership to describe the process through which the leadership practices of all members of the educational community are created, developed and consolidated including teachers, students, families, nonteacher staff, volunteers and other community members. Framed within the approach of leadership as a dialogic relationship, a core element in practicing leadership is the promotion of diverse and multiple dialogic and egalitarian interactions among the entire educational community, including the interactions that occur not only at home but also in the community. These authors argue that all social actors, in their commitment as dialogic leaders, can seek mechanisms to work together to support and promote actions that enhance the transformation of both the school and the community. Other research has analyzed how the dialogic approach is based on different social movements that have appeared in recent years in Spain, such as the $15 \mathrm{M}$ and the Affected by the Mortgage Platform (Rivero, 2013) movements. In this way, the social movements' leadership resembles what Flecha, Gómez \& Puigvert (2003) have called the dialogic turn of societies and social sciences, that is, the citizenry's claim in 


\section{Valls et al. - Leadership in Social Movements}

contemporary information society to substitute old forms of hierarchical decision-making processes for more dialogic-based ones.

Consistent with this prior work, the present article analyzes specific features of the leadership that was developed by Ester in Ojo con tu ojo (Watch out for your eye). In particular, this study explores the extent to which Ester's prior involvement in participative organizations that operated on the basis of dialogic and egalitarian principles contributed to the development of the movement. This study also examines how her particular form of leadership has been instrumental to the success of the organization, which has achieved important legislative changes regarding the use of rubber bullets by the Catalan police.

\section{Methods}

This study used the communicative methodology of research (Gómez, Puigvert \& Flecha, 2011). This approach seeks spaces for egalitarian dialogue to break with the epistemological imbalance and interpretative hierarchy between the researcher and the participant. Thus, the data that are collected from reality are interpreted in an intersubjective fashion. This approach acknowledges the capacity of social agents to interpret and therefore transform social reality (Gómez, Munté \& Sordé, 2014).

\section{Participants and Data Sources}

The following four data collection techniques were used and triangulated to bolster validity: (1) a communicative daily life story; (2) in-depth interviews; (3) communicative observations; and (4) a documentary analysis of the information that relates to the case. Table 1 summarizes the participants' profiles, as well as the different data collection techniques that were used in this study. Table 2 provides an overview of the communicative observations. 
Table 1

COMMUNICATIVE DAILY LIFE-STORIES AND INTERVIEWS

Technique Code Profile Occupation Age Gender Academic level

\begin{tabular}{lllllll}
\hline Life story & RC1 & Leader & Unemployed & 42 & Woman & Secondary education \\
Interview & E1 & $\begin{array}{l}\text { Movement's } \\
\text { participant }\end{array}$ & Dancer & 38 & Woman & Graduate in theater \\
Interview & E2 & $\begin{array}{l}\text { Manager's } \\
\text { campaign }\end{array}$ & Unemployed & 40 & Man & $\begin{array}{l}\text { Graduate in industrial } \\
\text { engineering }\end{array}$ \\
Interview & E3 & $\begin{array}{l}\text { Economy's } \\
\text { manager }\end{array}$ & $\begin{array}{l}\text { Childhood } \\
\text { educator }\end{array}$ & 30 & Woman & $\begin{array}{l}\text { Graduate in Geography } \\
\text { and History }\end{array}$ \\
\hline
\end{tabular}

Table 2

OBSERVATIONS

Code Technique

Description

Participants' number

O1 Observation Community dinner. November 17, 2012

500

O2 Observation Faculty of Economy and Business and

100

Ojo con tu ojo in support of Ester Quintana.

December 19, 2012

O3 Observation Community lunch "Paellada popular".

November 10, 2013 


\section{Valls et al. - Leadership in Social Movements}

A communicative daily life story was conducted with Ester, the leader of Ojo con tu ojo. This dialogue was structured around different sessions in which the interviewer and Ester jointly reflected on the background of the social movement, the characteristics of the leadership in this movement and how her participation in previous movements had influenced her and consequently influenced the Ojo con tu ojo movement. The narrative was developed over two meetings of more than two hours each.

Furthermore, three communicative in-depth interviews were conducted with Ojo con tu ojo activists. These interviews were based on an intersubjective dialogue between the interviewer and the study participants. The focus was on analysing how the participatory process had been developed and the role of Ester's leadership in this movement.

To gain a greater understanding of the leadership model of Ojo con tu ojo, three communicative observations were conducted. The first observation was conducted three days after the general strike in which Ester lost her eye. In a community dinner that was organized for the neighborhood's feast day and in front of an audience of 500 people, Ester's friends explained what had occurred and shared with the audience their plan to start a campaign for justice. Most importantly, this space was shared by many people who knew and appreciated Ester. Furthermore, discussions with different community members on this issue were held at this community dinner. The second observation occurred at an event that was held at the Faculty of Economics at the University of Barcelona. At this event, a member of Ojo con tu ojo presented the movement to students and faculty members. The third observation was held one year after the incident at the "Paellada popular", a community lunch that was organized during the neighborhood's feast. During the Paellada, an information booth on Ojo con tu ojo dispensed information concerning the movement to raise awareness regarding the actions had been undertaken and to engage in conversations with the people at the festivity.

Similar to participatory observations, communicative observations imply the direct participation of the researcher. However, in communicative methodology, the observer and the subject of the observation interact and share the meanings and interpretations regarding the actions and realities that are the objects of study.

Finally, the information that was gathered through communicative data collection techniques was complemented with a documentary analysis of 
the non-technical literature (Corbin \& Strauss, 2014) regarding Ester and the Ojo con tu ojo movement, including reports, news and media releases.

All of the information that was collected through the different data collection techniques was analysed to reconstruct Ester's experiences of democratic participation in different stages of her life and to identify the extent to which she transferred these prior experience to Ojo con tu ojo.

\section{Setting the Scene: Ester Quintana, the last victim to be injured by a rubber bullet in Catalonia}

Ester participated in the demonstration that was held in Barcelona on November 14, 2012. When she was leaving the demonstration with her friends, Ester was hit by a projectile that was shot by the Catalan Police. As a result, she lost her left eye and had several bone fractures in her face and additional traumatic impact. She was brought to the hospital that night and was not discharged until November 20. Since then, she has undergone several surgeries.

The use of non-lethal projectiles by the Spanish police was introduced more than 40 years ago. Non-lethal projectiles are also used by the anti-riot police in France and Portugal, whereas in Italy their use is much more restricted; in Germany, Greece and Norway, they are forbidden (STOP Bales de Goma [Stop rubber bullets], 2013). In the UK, the use of nonlethal projectiles dates back to 1970 (British Parliament, 2006). Over the years, the composition of non-lethal projectiles has changed, but they still remain a controversial weapon. The Human Rights Nineteenth Report of the British Parliament states that "Although these developments in the weapon have been presented as reducing its potential for injury, their claims to provide less lethal alternatives have been disputed" (2006, para 172). Wright (1998) warned against an extension of the use of non-lethal weapons and emphasized the need for democratic control over their use and dissemination.

In Spain, rubber bullets have other victims in addition to Ester: 9 people have been killed by rubber bullets and 26 have lost an eye, 7 of whom lost an eye during the last three years in Catalonia. More than 30 people have suffered permanent injuries (Ombudsman of Catalonia, 2011; STOP Bales de Goma, 2013). The European Commission advocated the ban of rubber bullets by the end of 2012 at the latest. However, despite European 


\section{Valls et al. - Leadership in Social Movements}

directives, the prohibition of rubber bullets was not achieved until late 2014 and was caused by the pressure of the Ojo con tu ojo campaign.

The responses to the injury that Ester suffered were twofold. On the one hand, the police commanders and their political leaders denied that there was any connection between the loss of her eye and the police's performance. Initially, officials denied that policemen with guns had been near the scene of the incident and that rubber bullets had been used. This denial lasted until the Catalan Minister of Home Affairs was replaced. Additionally, the officials' attitude towards Ester was marked by a lack of communication and interest in her well-being. Only in July 2015, during the trial, one of the alleged policemen admitted that he had fired rubber bullets at the time and place where Ester suffered its impact.

On the other hand, immediately after the incident, Ester's friends began to organize. For instance, they set up a press conference on the day that Ester was released from the hospital to obtain citizens' support videos, images and information regarding what had occurred during the demonstration and to show the real cause of Ester's injury. In response to this call, many citizens, shops and other establishments, and several journalists provided videos that showed images of the area where Ester was attacked to help clarify the events.

One month after the incident, the case became not only a part of the public debate but also a part of the political agenda. The Catalan Minister of Home Affairs was forced to provide explanations, apologize to the Parliament of Catalonia and rectify its previous versions of the facts. There were several dismissals within the Catalan Police. Finally, on December 27, 2012, a new Minister of Home Affairs was appointed. On February 2, 2013, the board of the spokespersons of the parliamentary groups of the Catalan Parliament accepted a proposal to create a commission to discuss the use of anti-riot projectiles, which was established on April 26, 2013. Simultaneously, a judge was still investigating the actions of the policemen and accused one officer as the person who fired the gun and consequently, also accused his superior officer. Recently, the prosecutor who is handling the case has requested two years of prison for the two accused officials because of the aggression that Ester suffered.

After the work of the commission and hearing the testimony of the victim, the police and the experts, the commission of the Catalan Parliament suggested among other measures "the immediate withdrawal of 
rubber bullets, to be gradually replaced, so that on April 30, 2014 a total ban would be effective" (Parliament of Catalonia, 2013, p.56). The proposal that bans the use of rubber bullets has been approved by the Parliament of Catalonia (Parliament of Catalonia 2013, p.71). In September 2015, the Catalan government has compensated Ester with 260,000 euros, which recognizes that she lost her eye in the general strike of November 14, 2012 because of police action. However, she went to trial and asked for 2 years for a police officer and a sub-inspector, but in May 2016 Barcelona Court absolved them.

\section{Findings}

First, we present the results regarding the dialogic background that Ester gained in her previous participation in social movements and dialogic experiences. Second, by drawing on this previous experience, the results on how this previous knowledge has been transferred to Ojo con tu ojo by Ester are presented.

\section{Ester Quintana's previous participation in grassroots dialogic movements}

Ester's trajectory has been marked by numerous experiences in grassroots social movements, which have significantly contributed to shape the leadership strategies that she has utilized in the Ojo con tu ojo movement. After finishing high school, Ester decided to look for a job rather than to continue studying. To be eligible for benefits, the employment office obliged her to participate in vocational training at the Escola Taller Can Cadena [Vocational Training School Can Cadena] in the neighborhood of La Verneda-Sant Martí ${ }^{2}$ in Barcelona. During this experience, she met the vast majority of the men and women who years later would create the Ojo con tu ojo movement. The friendships that were established over the years have created and strengthened the relational and emotional bonds that have shaped what Nepstad (2004) defines as a sense of activist identity. As expressed by Ester,

I ended at the Vocational Training School Can Cadena. There, I learned to share experiences with other people. I met lots of different people and 
some of them were from the La Verneda neighborhood, and I started to participate there. $(\mathrm{RC} 1)$

There, Ester first came into contact with and participated in different grassroots social movements, from feminist to anti-military movements. Ester and her friends decided to launch activities for young people in the neighborhood and created the NGO Espai Jove [Youth Space]. In the following quote, Ester describes her start in participatory movements.

At the vocational training school, I met many people from different movements, Mili- kaka, Eix-violeta. I didn't know them before. When all of these young people got organized and decided to throw a party, that's when Espai Jove was born. I have participated since it started, and now we have Ojo con tu ojo. Not everyone from Espai Jove is here (in Ojo con tu ojo) now, because life changes. My involvement in grassroots social movements began there. (RC1)

Once she finished the vocational training course, Ester started to volunteer in the ICT section of the Adult School of La Verneda-Sant Martí. This school, which is located in a working-class neighborhood in Barcelona, provides education to more than 1,700 participants, many of whom belong to vulnerable groups (i.e., young people with a low educational level, elderly women, people with a disability, migrants, etc.). The school's methodology is based on Freire's (1970) theory of dialogic action and Flecha's (2000) theory of dialogic learning (Aubert, Villarejo, Cabré, \& Santos, 2016). This basis is represented in the democratic governing bodies that comprise the adult students who manage the school, and these theories depart from Habermas's (1984) validity claims instead of power claims. At La Verneda, Ester had the opportunity to relate to many people (in terms of age, culture, religion and political orientation) and to learn about the dialogic approach under which the institution is organized. The school is fully managed by its participants, who are responsible for the decision-making on issues such as funding, scheduling and the selection of projects and activities to develop (Tellado, 2007). Ester identifies how her participation in La Verneda was a critical learning experience for her, which she has applied to her life. 
I volunteered at the Adult School. There, I changed; I started to be a person who communicated with other people. The fact that there were elderly people opened my mind. (RC1)

While she volunteered at the La Verneda Adult School, Ester had the opportunity to work at CREA, the Community of Research on Excellence for All. There, she received research training and became involved in projects that followed the communicative perspective of research. During her time in CREA, she participated in the Seminar with the book in hand, where she read the seminal works of Habermas, Freire and Touraine, among others, and discuss them with people with different academic backgrounds and mindsets. The principle that guided these discussions was the validity of the arguments rather than the status of the participants who formulated them. According to Ester, this experience was an intellectual revolution because, similarly to the La Verneda Adult School, in CREA, everything revolved around an egalitarian and intersubjective dialogue where all opinions were respected and encouraged, especially the voices that were traditionally silenced in academic circles such as hers from people without a university degree. According to Ester,

So through the school, I started to work at CREA. I worked there for three years until 2002. CREA (for me) was the "revolution of the letters", because suddenly I was in the academic world and fitting into it. I love the objectives of the work they do and the fact that their projects do not serve the purpose of making money but of giving people tools so that people can fulfill their own personal goals. There, I could participate in many intellectual debates, and I read Habermas. (RC1)

Furthermore, Ester's participation in egalitarian terms in academic discussions was an empowering experience that allowed her to be aware of the transformative potential of the interactions that occur in particular social and cultural settings as tools to promote social change (Freire, 1970; Mead, 1934; Vygotsky, 1978). In the following quote, Ester explains the relevance of these experiences.

I am "an object of study" of the projects of CREA and of what I learned there. It was very clear: I learned at CREA that talking and working 


\section{Valls et al. - Leadership in Social Movements}

together is the way to achieve more things rather than by using force. (RC1)

In addition to her research experience at CREA, Ester continued her involvement in Espai Jove and organized activities that included music and cultural exhibitions. For more than 20 years, Espai Jove has organized every year a "Paellada" during the neighborhood celebrations ${ }^{13}$. This event has become a multicultural and multigenerational space for the neighborhood. In this space, hundreds of people from the neighborhood showed their support for Ester after she was injured.

Furthermore, prior to her injury, Ester was managing the Sandaru bar in the Community Center of her neighborhood. During this occupational experience, she attempted to implement the principles that she had learned in her previous experiences. She transferred a democratic orientation to the management of the bar and involved people from the neighborhood in the organization of the social and cultural initiatives that were being promoted. The analysis of Ester's trajectory reveals the relevance of the former participatory experiences that shaped her leadership strategies in the new Ojo con tu ojo movement. Particularly, Ester emphasized the impact of her participation at the La Verneda Adult School where she was able to participate in its dialogic and democratic organization regarding the functioning of the school and the educational approach that was implemented there. Additionally, Ester emphasizes her experience at CREA, where she learned the most influential theoretical and practical approaches in the social sciences that attempt to overcome inequalities and participated in a dialogic environment that is open to the inclusion of all voices

\section{Transfer of Ester's prior experiences to Ojo con tu ojo}

This section analyzes the extent to which Ester's experiences in grassroots movements and at CREA has been transferred to the leadership that she developed in Ojo con tu ojo. Particularly, we focus on three principles that have guided the organizing of Ojo con tu ojo, namely, 1) egalitarian dialogue, 2) solidarity for social transformation and 3) embracing diversity. 


\section{Egalitarian dialogue}

The dialogic processes that Ester has experienced are based on principles such as the egalitarian dialogue (Flecha, 2000), the establishment of agreements on the basis of validity claims (Habermas, 1984) and the demonopolization of expert knowledge (Beck, 1992). These principles embrace the concept that all people can reflect and create knowledge regardless of their academic level and social status. The dialogic principles that have been learned by Ester in various experiences have been transferred to the participatory process of the Ojo con tu ojo movement. Ester clearly states how the participatory structure of Ojo con ojo, where all the participants have the right to be heard, was created because of her prior experiences in truly dialogic spaces, such as the La Verneda Adult School and CREA.

I learned that at CREA; I didn't learn that when I was a kid. I had a good basis, but I developed it there: to be more communicative, to promote more dialogue and participation among all people. And from the adult school, I also learned a lot. Everything at La Verneda School is very participatory, everything is decided among all, and I think that I took this way of doing things from these two places. Everything I learned there turned out to favor me, and it helped me very much. I try to put everything I learned into practice and now in Ojo con tu ojo. (RC1)

Ester enhanced this dialogic process by promoting collective leadership (Ganz, 2000). The strategy of the movement was built on a deliberative process. Since the days after the incident, when Ester and some close friends decided that they would react, each step and each action have been shared and discussed jointly. This process is because of Ester's goal to turn her story into a collective struggle. As she explains, "Ojo con tu ojo shares my philosophy; we are people who share the same ideas about how to act and we know each other very well" (RC1).

The leadership of Ojo con tu ojo relies on a participatory and democratic system of decision-making. Similar to other participatory movements in which Ester has participated, in Ojo con tu ojo, all members meet once a week and organize themselves into committees for specific tasks. 


\section{Valls et al. - Leadership in Social Movements}

Consistent with the research evidence on the benefit of friendship to the success of social movements (Shemtov, 2003), the role of friendship in Ojo con tu ojo has also been essential in promoting dialogic processes that are free from individual interests or desire for prominence. The feeling of friendship and esteem for Ester is the driving force that unites the promoters of Ojo con tu ojo and makes it possible for them to reach consensus, because they all want the best for their friend. A close friend of Ester's who is a member of Ojo con tu ojo states

The motivation to initiate Ojo con tu Ojo was the bond that resulted from our friendship. That's why we are so devoted and motivated and why we have achieved the incredible support that we got through social networks. (E2)

The important role of friendship among the promoters of the movement, as well as the leadership of Ester, is also recognized by another friend who is involved in Ojo con tu ojo.

The assembly works according to the criterion of confidence; we made the decisions without hoping to be the main figure. We were all guided by her. We reached consensus because we are friends. The esteem that we have for Ester was crucial for that. (E1)

\section{Solidarity for social transformation}

Solidarity for social transformation has been identified as one of the main principles of dialogic action (Flecha, 2000; Freire, 1970). Because of her previous experiences in which she got to know the potential of solidarity as a driving force for collective action, Ester was confident that this principle should be a main leadership feature of the movement.

Solidarity in Ojo con tu ojo has been visible in different dimensions. First, solidarity was instrumental in the definition of the movement's mission and scope. Since the incident, Ester was clear of her willingness to avoid new aggressions that are similar to the one that was perpetrated on her. Considering her situation, she did not resign and complain about it; instead, she put all of her knowledge into practice and in service of the public to help prevent other people from experiencing what happened to 
her. Ester's reaction to the aggression that she suffered and the actions that were taken by her and her friends show that solidarity is a pillar of this movement. Habermas (1994) analyzed the existence of three resources through which modern societies can address the process of exchange between the system and the life world, namely, money, power and solidarity. Ester's case is a clear example of a struggle that is based on commitment, solidarity and overcoming the feeling of being in an iron cage (Weber, 1978) that often invades individuals. In Ester's words, solidarity emerges as the basis of the movement.

I am a peaceful person and to be honest, I'm not very brave. I'd have never gotten into a place where I could see people who might cause a [potentially violent] situation ... so that this has happened to me is a very hard situation. I wouldn't wish it on anyone. I don't want this to happen again to anybody anymore. What you don't want for yourself you don't want it for others either, this is my philosophy. (RC1)

Second, solidarity has also become visible in the initial mobilization that reacted to Ester's injury, which enabled the beginning of the movement. The information that was gathered shows how the creation of Ojo con tu ojo was also an immediate supportive response for Ester's family and friends. Ester immediately made clear to them what type of movement should be organized. Thus, one of the main principles of this movement is the idea of turning Ester into "the last victim of rubber bullets" and distancing their claim from any feeling of vengeance or revenge. One of her friends expressed this movement of orientation towards solidarity with Ester and other victims during an event that was organized at the University of Barcelona.

Immediately (after the incident) we met friends and family to respond in solidarity to what had happened to Ester and to denounce police violence. At that meeting, some profound doubts came up. Why the name Ojo con tu ojo? When we thought about the name of the movement, the first thing that came to mind was the expression "An eye for an eye". However, then we see that this wouldn't make sense, it reflects violence and revenge and that was not what we wanted. So we changed it to Ojo con tu ojo [Watch out for your eye]. (O2) 
The campaign that Ojo con tu ojo initiated had a significant impact and was highly participative. The first action that they undertook was to use social networks such as Facebook and Twitter to ask citizens for evidence of what had occurred. One of the promoters of Ojo con tu ojo explains it as follows:

On Facebook and Twitter, we asked for the participation of people who had been in the same place as the incident and to provide proof, testimonies and videos of it. Furthermore, as her friends, we needed to make it public. The first thing we did was to look for other cases on the Internet, information, write e-mails to the people we knew to have a background in what had happened, and we made a network with friends. (E2)

Third, the solidarity that was the driving force of Ojo con tu ojo was transferred from Ester and her friends to the general public. The activities that were developed by Ojo con tu ojo addressed many aspects; in legal terms, a report was filed against the police and a public complaint was initiated regarding Ester's experience, and generally, the movement sought an absolute ban on rubber bullets. One of the strengths of this campaign was a video ${ }^{3}$ that was posted on the Ojo con tu ojo website on December 14, 2012, a month after the incident. In this video, Ester provides her version of the facts and complains about the police's refusal to accept responsibility for this matter. Ojo con tu ojo also granted interviews to selected media to assure that the reported news did not cause pity but rather awakened the collective solidarity with the victim to achieve a recognition of the facts and a total ban on the use of rubber bullets.

The reaction of the public was immediate. The movement obtained dozens of testimonies and recordings concerning the incident. One of these recordings was key for the Catalan Minister of Home Affairs to finally acknowledge that the police had used rubber bullets. The solidarity campaign that was launched by Ojo con tu ojo was impressive. More than 2,500 people, including famous people (writers, artists, musicians and journalists), entire families, elderly people, inhabitants of Ester's neighborhood and many others took pictures of themselves with one eye covered and posted them on social networks. Through the social networks, 
thousands of diverse people showed their solidarity with Ester. In this way, a movement that started in Barcelona soon spread to the rest of Spain and to the international arena. One of the spokespersons of Ojo con tu ojo explains how they achieved the support of so many diverse people.

First we had the support of people from the world of music, actors, and gradually we gained support from all kinds of people, from writers, journalists and well-known intellectuals to people of all types. $(\mathrm{O} 2)$

Similarly, Quintana reports some of the countless signs of public support that she received from many different people.

For example, the guy who works at the veterinary center in the neighborhood. One day when I passed by, he came out of the door and said, "You're Ester Quintana, right?" And he squeezed my hand so hard that I had to say, "wow, you're hurting me". Or on the bus many people approach me and give me their support. Or, for example, today I have been to Encants ${ }^{4}$ and three people stopped me. There was a guy who was making a delivery and he said, "You are Ester Quintana, right?" I was overwhelmed, it's incredible. "You're the girl!" they said, "you're the girl”. (RC1)

Ojo con tu ojo is an unusual and participatory social movement that changed the police system through the solidarity of the life world (Habermas, 1984) through a collective leadership and strategy that achieved considerable support from society. Creating a public debate on the use of rubber bullets against citizens had an unprecedented political and social impact. This process is consistent with the explanation of the analysis that Flecha, Soler-Gallart \& Sordé (2015) developed regarding how social impact can be achieved.

\section{Embracing diversity}

Strategic capacity and collective leadership are crucial to the effectiveness and success of social movements (Ganz, 2009). Some of the strategies that Ester promoted, such as collective decision-making, directly relate to the diverse processes of interaction and deliberation in which she had 


\section{Valls et al. - Leadership in Social Movements}

previously participated. Ester learned leadership from many different interactions such as the dialogue with young and elderly people, with people without an academic degree, and with people of diverse ideologies. She also learned from the dialogue with academics and social scientists that was based on arguments instead of on their power positions. Ester puts it very clearly: "I also do not know if the response that I had would have been the same if it had been someone else. The context I am navigating and all the things in which I have participated before, and my way of being and seeing things might have influenced [the response]." (RC1)

According to Ester and her friends, the diversity of the interactions that she had during her process of leadership learning has been essential for the Ojo con tu ojo movement to be pluralistic, pacific, consistent with the rejection of police violence, and based on communicative processes with the participation of diverse people. Ester's position has been crucial in providing the movement with this orientation. According to Ester,

Ojo con tu ojo is a peaceful movement because we didn't adhere to any particular ideology, because we welcome any of them. We are against violence, against projectiles and for more security. We have always decided that our actions should not be violent. I told them from home (to her friends from Ojo con ojo when she was still a convalescent) that it mustn't be violent; it is better to give badges than to throw tomatoes on the Ministry. (RC1)

Apart from this position and character, Ojo con tu ojo is a non-political, non-official organization. It is a group of people without association status. However, considering the increase in governance proposals that emerge from deliberative processes (Elster, 1998), Ojo con tu ojo is building a radicalized democracy that emphasizes the gestation of new policies that reflect the dialogic character of both Ojo con tu ojo and society. The members never wanted the movement to be considered a political movement or be politically labelled because they felt distant from politicians. However, Ojo con tu ojo understood the importance of having political impact, which it has fully succeeded in. Additionally, the movement did not take a stand in favor of or against any political party. Rather, Ojo con tu ojo attempted to not lose sight of its goal. Ester explains this perspective as follows: 
"They are this, they are that". No! What I stand for is that if you (politicians) agree with us, great, but we don't go against the one who disagrees with us, because the only thing you will achieve with that is to have the general public against you. This is not a struggle among us, but we need to join forces among all of us. (RC1)

For Ojo con tu Ojo to reach people, it was crucial not to be labelled as a youth or anti-system movement. The movement wanted people to identify with the victim and her story. Ester explains how she insisted to the members of Ojo con tu ojo that they must respect everybody and how they had decisive conversations on this issue with all members.

Of course there were people who would have wanted to do different kinds of actions. Once I saw graffiti of Ojo con tu ojo on the walls of the subway. I explained it in a meeting and we talked about it. I don't want people to think that we're drawing on the subway walls. We need to take into account that other people feel differently about that. We always need to respect the thoughts of others. (RC1)

The movement gathers highly diverse people from other movements that struggle for the same cause. Some Ojo con tu ojo members and Ester explain this recruitment as follows:

We had to reach out to all collectives, and it had to be a nice campaign, attempting to seek the positive aspects to promote, strengthen the identification with Ester, and that what happened to her could have happened to anybody. (E2)

We had to fight against impunity and raise people's awareness. (E1)

Many people identified themselves with me, a middle-aged woman who is not antisocial. I'm not a squatter, I'm not radical in any sense, you know, so any woman could identify with me, and I know this was important. One of the things we did was to reach out not only to people of our age or our lifestyle. We wanted the message to get across widely. $(\mathrm{RC} 1)$ 


\section{Valls et al. - Leadership in Social Movements}

The members of Ojo con tu ojo were also considerate in their discourse and the image that they presented at all times so that it would not build on hatred, aggression, or violent images but rather on a constructive discourse that would not criminalize the police and that would make everybody think that this could happen to them. The members wanted to develop an attractive movement to raise awareness through a well-designed campaign that promoted social change. Ester and two of her friends expressed it in the following terms.

It wasn't made with hatred in the sense of I want to wipe out this or that (politician or policemen) but explaining what happened in first person. I explained what happened to me. Now I want an answer, [I want to see] that justice is being done, and nobody else has to live this. This discourse of no more victims has been a hook for the people. This was very important because the day after uploading the video (in which Ester explains the facts), I received a call from Home Affairs (the Ministry of Home Affairs). Until that day, I hadn't received any call from anybody in the government asking how I felt or to officially apologize. However, after uploading the video to the social networks on November 29, I received a call the day after from Home Affairs asking me how I felt. (RC1)

We didn't criminalize the police. We didn't use any violent images. (E2) The criteria were to have an attractive campaign to everyone, to do things right and to be effective. (E1)

The pluralistic and inclusive orientation of Ojo con tu ojo, which was caused by Ester's efforts to transfer the characteristics that define the truly dialogic organizations to the movement, was instrumental to the result that was obtained. Ojo con tu ojo reached the structures and transformed the policies regarding the use of rubber bullets and other projectiles by the Catalan security forces.

\section{Conclusion}

Ester Quintana and the Ojo con tu ojo movement achieved in only one year what other movements had been attempting to do for many years: ban the use of rubber bullets by the police. The literature on leadership has shown 
that leaders' previous experiences have a decisive influence on the strategies that are developed in social movements (Nepstad, 2004; Nepstad \& Bob, 2006; Morris \& Staggernborn, 2002). Moreover, the ability of leaders to transfer the elements that have been effective in one movement to other movements and to promote collective forms of leadership may contribute to their success (Andrews et al. 2010; Baggetta et al. 2013; Morris \& Staggernborn, 2002). The data that were presented here corroborate these studies and add new knowledge to the study of leadership in social movements from the case study of Ojo con tu ojo and the analysis of the principles that were transferred by its leader, Ester, because of her previous participatory experiences.

This study has analyzed how Ester transferred all of her knowledge that was gained from her previous participatory and dialogic experiences to the development of Ojo con tu ojo. This participatory background is characterized by principles such as the egalitarian dialogue among all participants, solidarity for social transformation, and the importance of embracing diversity in all the spaces of debate and decision-making. Our analysis shows how this participatory background has been instrumental to the effectiveness of Ojo con tu ojo in successfully achieving one of its principal objectives - a legislative change - in a short period of time. Thus, Ester channeled her previous experiences through her prior history in participatory organizations to construct a narrative that empowered and mobilized many people to join her movement (Ganz, 2009; Morris \& Staggernborn, 2002). The Ojo con tu ojo movement that is led by Ester turned an individual injury into a collective struggle that was shared by many people who were in favor of banning the use of rubber bullets by the police.

Ojo con tu ojo continues to work against the violation of rights by unjustified police violence and to achieve justice for Ester. Although the police finally acknowledged the use of rubber bullets at the time when Ester was injured and there are two policemen who have been charged with the incident, the trial in which the citizen's jury will decide whether they will be held responsible for her injuries is still ongoing.

This study has advanced the available knowledge concerning leadership in social movements. With this research, specific knowledge on how the participatory and dialogic background of a leader can be transferred to new social movements may impact their results. More research on specific cases 


\section{Valls et al. - Leadership in Social Movements}

is needed to inform participatory and dialogic social movements and collective actions to increase their social and political impact.

\section{NOTES}

1 Ojo con tu ojo's official website and Facebook page: http://www.ojocontuojo.org/en US; https://www.facebook.com/ojocontuojo2012

$2 \mathrm{La}$ Verneda is a working-class neighborhood which received immigration from the south of Spain during the 1950s. The neighborhood is marked by its struggles to improve the quality of life.

3 Ester Quintana's video "Perder un ojo" [Losing an eye] with English subtitles https://www.youtube.com/watch?v=ksm7f3eylbc

4 Encants is an antiques market.

\section{References}

Andrews, K.T., Ganz, M., Baggetta, H.H., \& Lim, C. (2010). Leadership, Membership, and Voice: Civic Associations that Work. American Journal of Sociology, 115(4), 1191-1242.

Aminzade, R., Goldstone, J., \& Perry, E. (2001). "Leadership Dynamics and the Dynamics of Contention." in Jack A.A., Goldstone, D., McAdam, Perry. E, J., Ronald R., Sewell, W., and S.Tarrow (Eds.). Silence and Voice in Contentious Politics, (pp. 126-154). Cambridge: Cambridge University Press.

Aubert, A., Villarejo, B., Cabré, J., \& Santos, T. (2016). La Verneda Sant Martí adult school: a reference of popular education in the neighborhoods. Teachers College Record, 118(4), 1-32.

Baggetta, M., Han, H., and Andrews, K. (2013). Leading Associations: How Individual Characteristics and Team Dynamics Generate Committed Leaders. American Sociological Review, 78(4), 544-573

Banaszak, L.A. (1996). Why Movements Succeed or Fail: Opportunity, Culture, and the Struggle for Woman Suffrage. Princeton: Princeton University Press.

Bandura, A. (1989). Social Cognitive Theory, In R. Vasta (Ed.). Annals of child development. Vol. 6. Six theories of child development, (pp. 160). Greenwich, CT: JAI Press.

Beck, U. (1992). Risk Society: Towards a New Modernity. London: Sage. 
British Parliament. (2006). Joint Committee on Human Rights Nineteenth Report. London. Retrieved from https:/www.publications.parliament.uk/pa/jt200506/jtselect/jtrights/1 85/18512.htm

Corbin, J., \& Strauss, A. (2014). Basics of qualitative research (4th ed.). Thousand Oaks, CA: Sage.

Couto, R. A. (1993). Narrative, Free Space, and Political Leadership in Social Movements. The Journal of Politics, 55(1), 57-79.

Davis, J. E. (2002). Narrative and Social Movements. The Power of Stories, In J. E. Davis (Ed.). Stories of Change: Narrative and Social Movements, (pp. 3-39). Albany: State University of New York.

DiMaggio, P. (1997). Culture and Cognition. Annual Review of Sociology, 23(1), 263-287.

DiMaggio, Paul J. \& Powell, Walter W. 1991. "Introduction.” In DiMaggio, P. \& W. Powell (Eds.). The New Institutionalism and Organizational Analysis, (pp. 1-38). Walter, Chicago: University of Chicago Press.

Downey, D. J. (2006). The Role of Leadership and Strategy in Navigating Political Incorporation: Defining a Niche for Human Relations in Orange County, California, 1971-2000. The Sociological Quarterly, 47 (4), 569-597.

Einwohner, R.L. (2007). Leadership, Authority, and Collective Action Jewish Resistance in the Ghettos of Warsaw and Vilna. American Behavioral Scientist, 50 (10), 1306-1326.

Elster, J. (Ed.). (1998). Deliberative Democracy. Cambridge: Cambridge University Press.

Flecha, R. (2000). Sharing Words. Lanham, M.D: Rowman \& Littlefield.

Flecha, R, Gómez, J., \& Puigvert, L. (2003). Contemporary Sociological Theory. New York: Peter Lang.

Flecha, R., Soler-Gallart, M., \& Sordé, T. (2015). Social impact: Europe must fund social sciences. Nature 528(7581), 193-193.

Freire, P. (1970). Pedagogy of the Oppressed. New York: Continuum.

Ganz, M. (2000). Resources and Resourcefulness: Strategic Capacity in the Unionization of California Agriculture, 1959-1966. American Journal of Sociology, 105(4), 1003-1062.

Ganz, M. (2009). Why David sometimes wins. Oxford: Oxford University Press.

Ganz, M. (2010). Leading Change. Leadership, Organization, and Social Movements, In Nohria, $\mathrm{N}$ and R. Khurana (Eds.). Handbook of 
174 Valls et al. - Leadership in Social Movements

Leadership Theory and Practice: A Harvard Business School Centennial Colloquium (pp. 509-550). Boston: Harvard Business Press.

Ganz, M. (2011). Public Narrative, Collective Action, and Power, In Odugbemi, S., and T Lee (Eds.), Accountability through Public Opinion: From Inertia to Public Action, (pp. 273-289). Washington, DC: The World Bank.

Gómez, A., Puigvert, L., \& Flecha, R. (2011). Critical Communicative Methodology: Informing Real Social Transformation through Research. Qualitative Inquiry, 17 (3)235-245.

Gómez, A., Munte, A., \& Sorde, T. (2014). Transforming schools through minority males' participation: Overcoming cultural stereotypes and preventing violence. Journal of interpersonal violence, 29(11), 20022020.

Gomez-Roman, C., \& Sabucedo, J. M. (2014). The importance of political context: Motives to participate in a protest before and after the labor reform in Spain. International Sociology, 29(6),546-564.

Jiménez, B. R. (2013). New social movements in Spanish State: a view from the principles of dialogic learning. International and Multidisciplinary Journal of Social Sciences, 2(3), 273-296.

Habermas, J. (1984). The Theory of Communicative Action. V. 1. Reason and the Rationalization of Society. Boston: Beacon Press.

Habermas, J. (1994). Democratic and Constitutional Theory Today. Three Normative Models of Democracy. Constellations, l (1)1-10.

Lynch, A. P. (2016). Politics, recognition, and personality: Selfhood and social change in late modernity. International Sociology, 31(5), 533542. doi: https://doi.org/10.1177/0268580916655751

Mead, G. H. (1934). Mind, Self and Society. Chicago: University of Chicago Press.

Melucci, A. (1996). Challenging Codes: Collective Action in the Information Age. Cambridge: Cambridge University Press.

Morris, A. (2000). Reflections on Social Movement Theory: Criticisms and Proposals. Contemporary Sociology, 29(3), 445-454.

Morris, A., \& Staggernborn. S. (2004). Leadership in Social Movements, In Snow, D.; Soule, S.A., and H. Kriesi (Eds.). The Blackwell Companion to Social Movements (pp. 171-196). Malden, Oxford: Victoria: Blackwell Publishing. 
Nepstad, S. E. (2004). Persistent resistance: Commitment and community in the Plowshares movement. Social Problems, 51(1), 43-60.

Nepstad, S., \& Bob, C. (2006). When do leaders matter? Hypotheses on leadership dynamics in social movements. Mobilization: An International Quarterly, 11(1), 1-22.

Parliament of Catalonia. (2013). Informe de la Comissió d'Estudi dels Models de Seguretat i Ordre Públic i de l'Ús de Material Antiavalots en Esdeveniments de Masses [Report of the Commission for the Study of Models for Security and Public Order and Riot Material Usage in Mass Events] BOPC. Butlletí Oficial del Parlament de Catalunya [Official Bulletin of the Parliament of Catalonia]. November 25, 2013, 198:57-71. Retrieved from www.parlament.cat/activitat/bopc/10b198.pdf

Padros, M., \& Flecha, R. (2014). Towards a conceptualization of dialogic leadership. International Journal of Educational Leadership and Management, 2(2), 207-226.

Rivero, B. (2013). Nuevos Movimientos Sociales en el Estado Español: Una Visión desde los Principios del Aprendizaje Dialógico. International and Multidisciplinary Journal of Social Sciences, 2(3), 273-296. doi: 10.4471/rimcis.2013.25

Shemtov, R. (2003). Social Networks and Sustained Activism in Local NIMBY. Sociological Forum, 18(2), 215-24.

Soler, M. (2015). Biographies of "Invisible" People Who Transform Their Lives and Enhance Social Transformations Through Dialogic Gatherings. Qualitative Inquiry, 21(10), 839-842. https://doi.org/10.1177/1077800415614032

Ombudsman of Catalonia. (2011). Resolución de la Actuación de Oficio Núm. 2358/2011, Relativa al Uso de las Pelotas de Goma. [Resolution regarding to the Use of Rubber Bullets] Retrieved from http://www.sindic.cat/site/unitFiles/3378/Resolucion_pelotas_de_gom a_cast.pdf

STOP Bales de Goma. [STOP Rubber Bullets]. (2013). El uso de balas de goma por parte de la Brigada Móvil de los Mossos d'Esquadra (BRIMO) [The use of rubber bullets by the Mobile Brigade of the Catalan police]. Retrieved from http://stopbalesdegoma.org/wpcontent/uploads/2013/07/informe-SBG2013_ES.pdf

Tellado, I. (2007). Dialogic management in adult education: A case study in Spain. Northern Illinois University. 
176 Valls et al. - Leadership in Social Movements

Veltmeyer, H., \& Petras, J. (2002). The social dynamics of Brazil's rural landless workers' movement: Ten hypotheses on successful leadership. The Canadian Review of Sociology, 39(1), 79.

Vygotsky, L. (1978). Mind in Society. The Development of Higher Psychological Processes. Cambridge: Harvard University Press.

Weber, M. (1978). Economy and Society. Berkeley: University of California Press.

Wright, S. (1998). An Appraisal of Technologies for Political Control. European Parliament. Directorate General for Research. PE Number: PE 166 499. Pp. (26-31). Strasbourg: European Parliament. Retrieved from

http://www.europarl.europa.eu/pdf/jadis/2013_12/8.PE4_AP_PV!LIB E.1994_LIBE-199801260050EN.pdf

Zerubavel, E. (1997). Social Mindscapes: An Invitation to Cognitive Sociology. Cambridge: Harvard University Press. 
Rosa Valls is Professor of Education, University of Barcelona Address: Facultad de Educación. Passeig de la Vall d'Hebron, 171 Edifici Llevant $3^{\mathrm{a}}$ planta despatx $\mathrm{n}^{\circ} 346 \quad$ 08035- Barcelona, Spain Email: rosavalls@ub.edu

Adrian Aubert is Associate Professor at the Department of Sociology, University of Barcelona

Address: Facultat d'Economia i Empresa. Universitat de Barcelona Avda. Diagonal, 69008034 - Barcelona, Spain

Torre 4, Planta 1, despatx 4128

Email: adriana.aubert@ub.edu

Lídia Puigvert is Professor of Sociology, University of Barcelona Address: Facultat d'Economia i Empresa. Universitat de Barcelona Avda. Diagonal, 69008034 - Barcelona, Spain

Torre 4, Planta 1, despatx 4100

Email: lidia.puigvert@ub.edu

Ainhoa Flecha is Associate Professor at the Department of Sociology, Autonomous University of Barcelona Address: Departamento de Sociología

Avenida Eix Central. Edificio B. 08193 Bellaterra (Cerdanyola del Vallès) Despacho: B3-185, Spain

Email: Ainhoa.Flecha@uab.cat 